\title{
Case Report \\ Treatment of Vascular Lesions of the Tongue with Nd:YAG Laser
}

\author{
Joana Dias Coelho and Vasco Serrão \\ Department of Dermatology, Hospital dos Capuchos, Alameda Santo António dos Capuchos, 1169-050 Lisbon, Portugal \\ Correspondence should be addressed to Joana Dias Coelho, joanadiascoelho@hotmail.com
}

Received 1 September 2009; Accepted 17 November 2009

Recommended by Robert S. Dawe

The treatment of vascular lesions of the tongue is a very challenging procedure since the maintenance of the lingual tissue is of critical importance. Numerous treatment options have been described in literature but the Nd:YAG Laser appears to be one of the safest therapeutic options. We described a successful treatment of vascular lesions of the tongue with an excellent clinical result after only one treatment session with the Nd:YAG laser, with conservation of the lingual tissue and its functionality.

Copyright ( $\odot 2009$ J. Dias Coelho and V. Serrão. This is an open access article distributed under the Creative Commons Attribution License, which permits unrestricted use, distribution, and reproduction in any medium, provided the original work is properly cited.

\section{Case Letter}

Vascular lesions of the tongue are uncommon and can be associated with complications such as recurrent bleeding (secondary to minor trauma, tongue biting, or dental hygiene) and enlargement of the lesions with difficulty in chewing, swallowing, or speaking. They usually present as soft, compressible, nonpulsatile bluish mass, frequently isolated but may occur as a part of a systemic syndrome (Rendu-Osler-Weber, Blue rubber bleb nevus, and Maffucci's syndrome) [1].

Many different options for treatment are described in literature: surgery, embolization, steroid therapy, cryosurgery, electrodessication, CO2 laser, and Nd:YAG laser [2-6]. These treatments have different clinical and cosmetic results. It is important to prevent the destruction of tongue tissue that may lead to functional disability [7].

The Nd:YAG laser at $1064 \mathrm{~nm}$ has a high penetration depth of up to $5-6 \mathrm{~mm}$, since it is selectively absorbed by hemoglobin and poorly absorbed in water. Comparing to the traditional vascular lasers, it penetrates more deeply into the tissue, since light is less absorbed by the chromophore hemoglobin at the $1064 \mathrm{~nm}$ wavelength than at 530 to $600 \mathrm{~nm}$ wavelength. In addition, the Nd:YAG laser has a coagulative action as it passes through tissues [7-9].

We describe a case report of a 70-year-old woman with three bluish nodules on her tongue of 5 years' duration (Figure 1). No episodes of recurrent bleeding were present. Physical examination revealed two soft, dark-red nodules with $12 \times 10 \mathrm{~mm}$ suggestive of vascular lesions and a small nodule of $2 \times 2 \mathrm{~mm}$ in the tip of the tongue. No histological diagnostic was performed to avoid an unnecessary bleeding.

After proper antiseptic preparation (without local anesthesia), 3 passes of $50 \mathrm{~ms}$ with a fluence of $130 \mathrm{~J} / \mathrm{cm}^{2}$ were used ( $5 \mathrm{~mm}$ spot). Clinical end points were the shrinkage and blanching of the lesion. No adverse reactions were present.

An excellent result was obtained with only one treatment session. A complete response was present after a 6-month follow-up (Figure 2).

\section{Discussion}

Treatment of vascular malformations of the tongue may be very challenging since the use of a procedure that conserves the lingual tissue and its functionality is essential.

In literature, there are some reports about the efficacy of the Nd:YAG Laser in the treatment of vascular malformations of the face and neck [10-12]. Classic surgery has a lower risk of recurrence; however, complications, such as bleeding, shortness of breath, or infection and incomplete response can occur [13].

In our case report, we obtained an excellent result with a complete response to a single treatment. No complications were present.

We believe that the Nd:YAG Laser is a very good option for the treatment of vascular lesions in the tongue, being a safe, easy, and effective procedure with short downtime and 


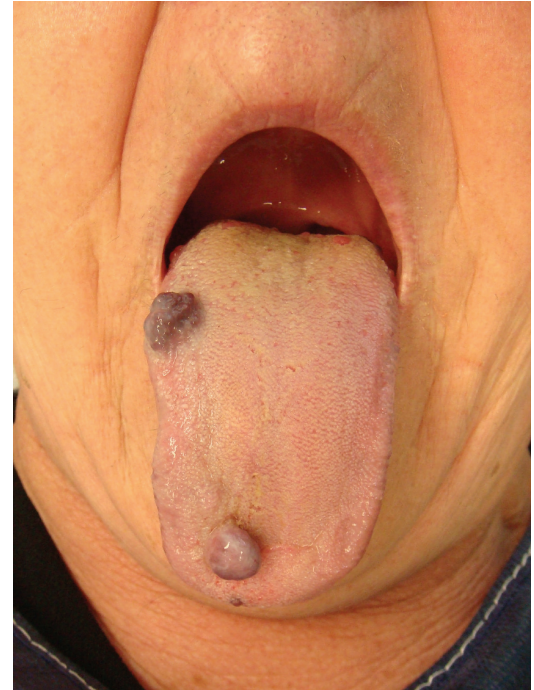

Figure 1: Two soft, dark-red nodules with $12 \mathrm{~mm} \times 10 \mathrm{~mm}$ suggestive of vascular lesions and a small nodule of $2 \times 2 \mathrm{~mm}$ in the tip of the tongue are present.

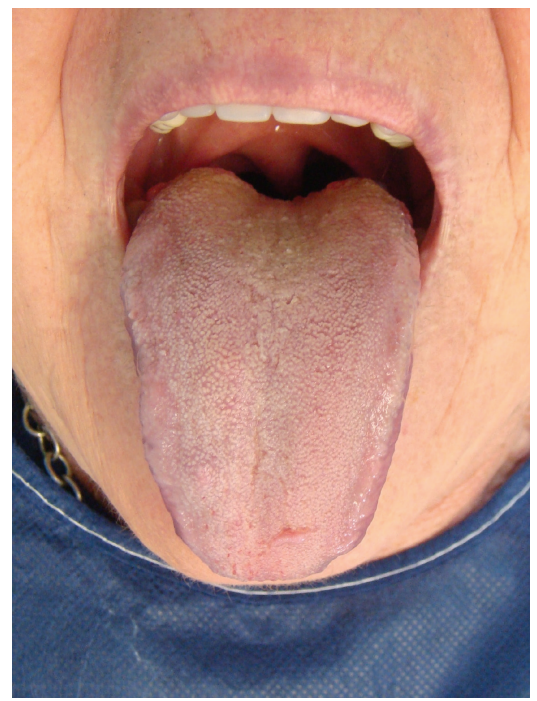

FIgURE 2: Complete response after only one treatment session.

an excellent maintenance of the lingual tissue, especially in thick or nodular lesions.

\section{References}

[1] J. A. Dixon, R. K. Davis, and J. J. Gilbertson, "Laser photocoagulation of vascular malformations of the tongue," Laryngoscope, vol. 96, no. 5, pp. 537-541, 1986.

[2] H. Miyazaki, J. Kato, H. Watanabe, et al., "Intralesional laser treatment of voluminous vascular lesions in the oral cavity," Oral Surgery, Oral Medicine, Oral Pathology, Oral Radiology and Endodontology, vol. 107, no. 2, pp. 164-172, 2009.

[3] V. M. López Pérez, C. M. Hernández Cañete, and E. Rodríguez Moreno, "Sclerosing therapy in hemangiomas of the tongue," Angiologia, vol. 43, no. 6, pp. 228-230, 1991 (Spanish).
[4] D. B. Apfelberg, M. R. Maser, H. Lash, and D. N. White, "Benefits of the $\mathrm{CO}_{2}$ laser in oral hemangioma excision," Plastic and Reconstructive Surgery, vol. 75, no. 1, pp. 46-50, 1985.

[5] J. P. H. Bekke and J. A. Baart, "Six years' experience with cryosurgery in the oral cavity," International Journal of Oral Surgery, vol. 8, no. 4, pp. 251-270, 1979.

[6] S. R. Cohen and C. I. Wang, "Steroid treatment of hemangioma of the head and neck in children," Annals of Otology, Rhinology and Laryngology, vol. 81, no. 4, pp. 584-590, 1972.

[7] A. Vesnaver and D. A. Dovsak, "Treatment of vascular lesions in the head and neck using Nd:YAG laser," Journal of CranioMaxillofacial Surgery, vol. 34, no. 1, pp. 17-24, 2006.

[8] K. Scherer and M. Waner, "Nd:YAG lasers $(1,064 \mathrm{~nm})$ in the treatment of venous malformations of the face and neck: challenges and benefits," Lasers in Medical Science, vol. 22, no. 2, pp. 119-126, 2007.

[9] C.-J. Chang, D. M. Fisher, and Y.-R. Chen, "Intralesional photocoagulation of vascular anomalies of the tongue," British Journal of Plastic Surgery, vol. 52, no. 3, pp. 178-181, 1999.

[10] A. Idígora, A. Morelló, F. Sabater, M. Maristany, I. Vilaseca, and J. Traserra, "Yag-laser for the treatment of laryngeal and oral hemangiomas," Anales Otorrinolaringológicos IberoAmericanos, vol. 23, no. 2, pp. 179-188, 1996.

[11] M. A. Clymer, D. S. Fortune, L. Reinisch, D. M. Toriumi, J. A. Werkhaven, and W. R. Ries, "Interstitial Nd:YAG photocoagulation for vascular malformations and hemangiomas in childhood," Archives of Otolaryngology, vol. 124, no. 4, pp. 431-436, 1998.

[12] L. Gáspár, M. Kásler, G. Szabó, and F. Bánhidy, "Separate and combined use of Nd:YAG and carbon dioxide lasers in oral surgery," Journal of Clinical Laser Medicine \& Surgery, vol. 9, no. 5, pp. 381-383, 1991.

[13] A. Kutluhan, K. Bozdemir, and S. Ugras, "The treatment of tongue haemangioma by plasma knife surgery," Singapore Medical Journal, vol. 49, no. 11, pp. e312-e314, 2008. 


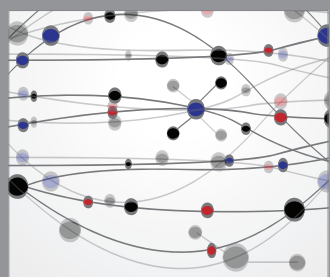

The Scientific World Journal
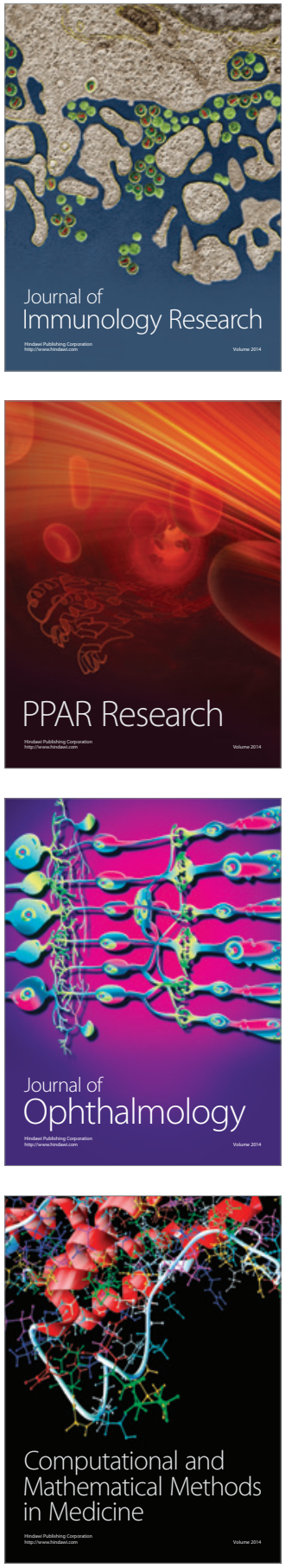

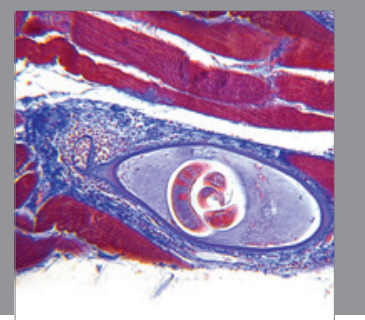

Gastroenterology

Research and Practice
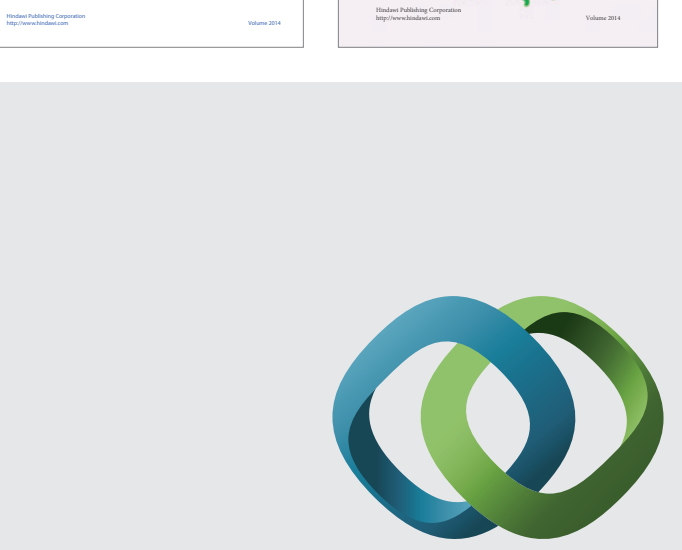

\section{Hindawi}

Submit your manuscripts at

http://www.hindawi.com
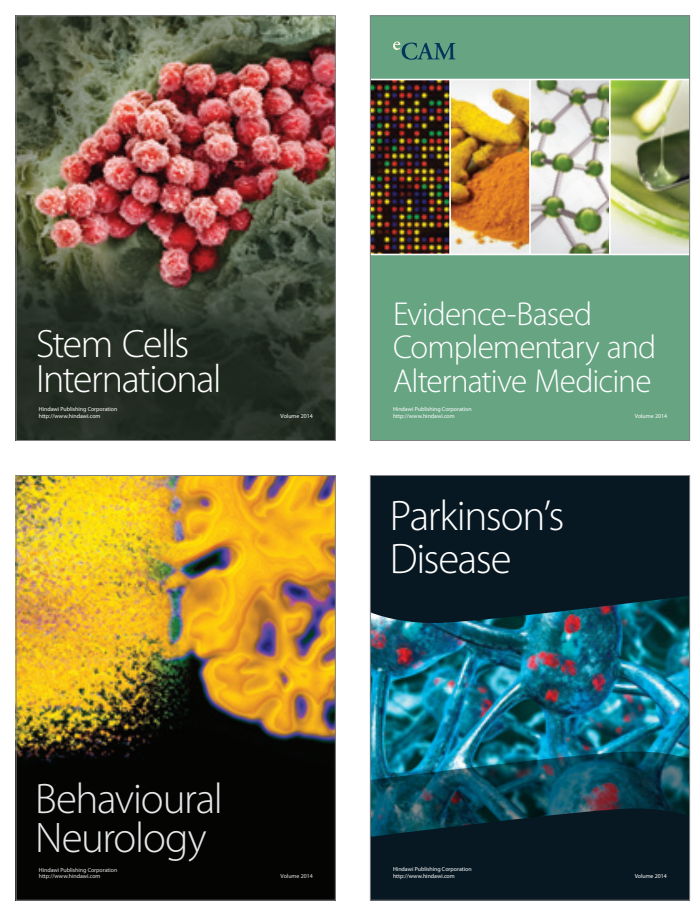

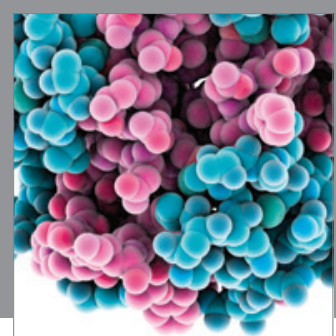

Journal of
Diabetes Research

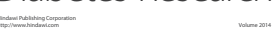

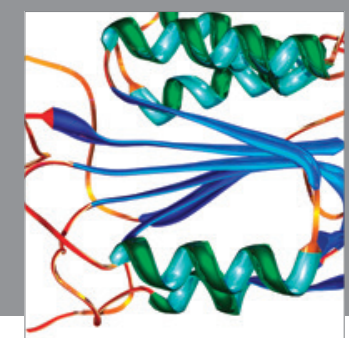

Disease Markers
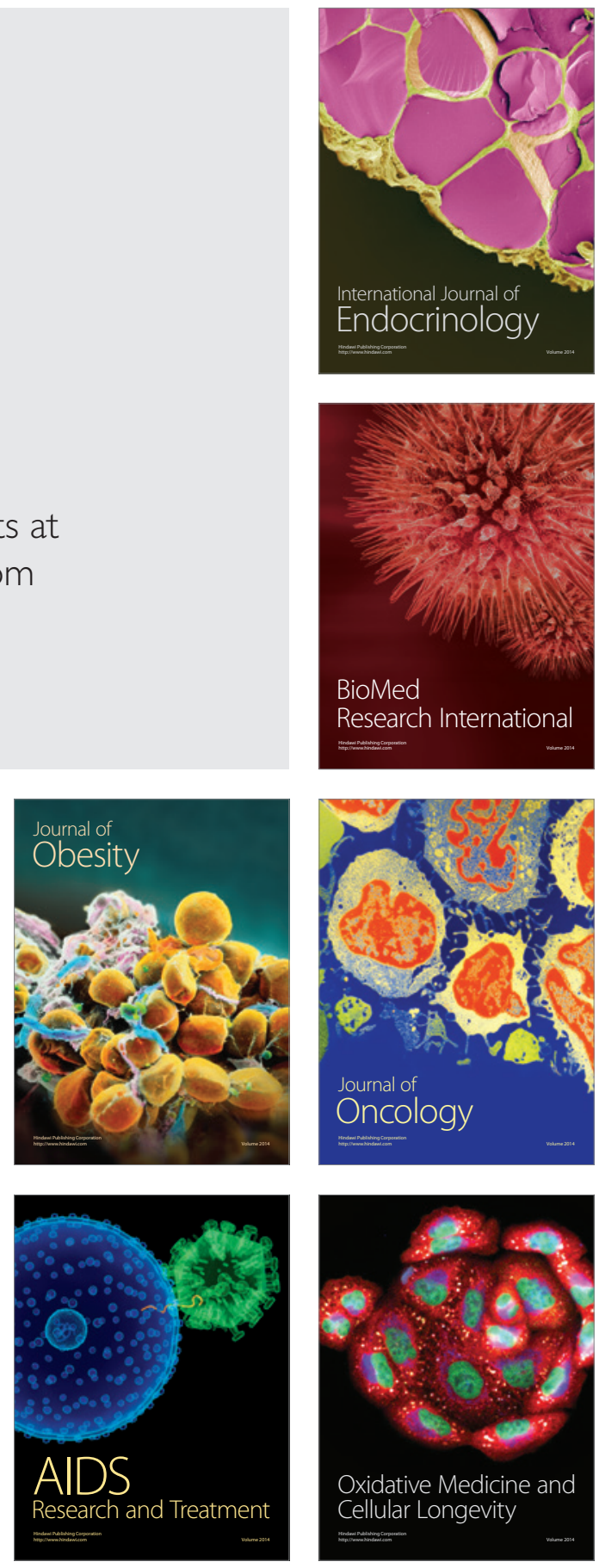